\section{ANALISIS PENGAKUAN PENDAPATAN DAN BEBAN DALAM LAPORAN LABA RUGI PADA PT. MONIFORI NUSANTARA.}

\author{
David HM Hasibuan dan Fira Fitriantika \\ Program Studi Akuntansi, Sekolah Tinggi Ilmu Ekonomi Kesatuan \\ Bogor, Indonesia \\ Email : lemlit@stiekesatuan.ac.id
}

\section{ABSTRACT}

Income statement contains information about a company's activities in a certain period more specifically its' profits and loss, in which revenues and expenses are recognised. The research aims at analysing the recognition of revenues and expenses by a firm to compose an income statement. Analysis is conducted to discover if PT Monifori Nusantara has applied the general accounting standard. the result show that the aforementioned firm conducted a proper and accountable revenues and expenses recognition. The result also shows that electicity and depreciation expenses are not in accordance to the generally accepted accounting standard, this is because those expenses were not recognised into their own accounts.

Key words: revenues and expenses recognition, income statement

\section{PENDAHULUAN}

Setiap perusahaan menginformasikan laporan mengenai aktivitas ekonomi dan kondisi dari perusahaan kepada pihak-pihak yang berkepentingan dengan menggunakan suatu ilmu ekonomi yang disebut dengan Akuntansi. Akuntansi sangat berkaitan dengan pencatatan dan pelaporan data serta kegiatan ekonomi perusahaan untuk diinformasikan kepada pemilik, kreditor, lembaga pemerintah dan masyarakat. Laporan data yang dimaksud adalah laporan keuangan dimana laporan tersebut digunakan untuk ditelaah dan dibandingkan kinerja keuangan dari suatu perusahaan. Kinerja perusahaan terlihat dalam laporan keuangan pada posisi laporan laba rugi dimana penghasilan atau pendapatan dan beban yang selalu diperhatikan dalam mengukur kinerja dan kondisi dalam suatu perusahaan.

Dalam kerangka Dasar Penyusunan dan Penyajian Laporan Keuangan , penghasilan merupakan kenaikan manfaat ekonomi selama suatu periodde akuntansi dalam bentuk pemasukan atau penambahan aset atau penurunan kewajiban yang mengakibatkan kenaikan ekuitas yang tidak berasal dari kontribusi penanam modal. Penghasilan meliputi pendapatan maupun keuntungan. Pendapatan adalah penghasilan yang timbul dari pelaksanaan aktivitas entitas yang normal dan dikenal dengan sebutan yang berbeda, seperti penjualan, penghasilan jasa, bunga, dividen, royalti dan sewa. Permasalahan utama dari akuntansi pendapatan adalah menentukan saat pengakuan pendapatan. Pendapatan diakui ketika kemungkinan besar manfaat ekonomi masa depan akan mengalir ke entitas dan manfaat ini dapat diukur secara tepat.

Beban termasuk jaminan dan biaya lain yang terjadi setelah pengiriman barang, biasanya dapat diukur secara andal jika kondisi lain untuk pengakuan pendapatan telah dipenuhi. Tetapi, pendapatan tidak diakui jika beban yang berkaitan tidak dapat diukur secara andal. Dalam keadaan tersebut, setiap imbalan yang diterima untuk penjualan barang tersebut diakui sebagai liabilitas.

PT Monfori Nusantara yang merupakan perusahaan manufaktur yang bergerak dibidang bioteknologi untuk melakukan pembudidayaan tanaman kehutanan,

\section{JIAKES \\ Jurnal Ilmiah Akuntansi Kesatuan Vol. 4 No. 1, 2016 pg. $007-013$ ISSN $2337-7852$}


revenues and expenses

recognition, income statement

\section{8}

khususnya kayu jati, juga perusahaan dagang yang menjual berbagai macam jenis tanaman dan bunga sampai ke luar Indonesia.Sebagai perusahaan manufaktur kegiatan penjualan PT Monfori Nusantara adalah kegiatan yang penting, karena dengan adanya kegiatan penjualan tersebut maka akan terbentuk pendapatan. Pendapatan yang ada memerlukan pengakuan agar pendapatan yang telah terjadi dapat diketahui kapan diakuinya. Hal yang sama juga berlaku pada beban yang terjadi pada perusahaan dalam menjalankan operasionalnya.

\section{MAKSUD DAN TUJUAN}

1. Untuk mengetahui pengakuan pendapatan dalam laporan laba rugi pada PT Monfori Nusantara.

2. Untuk mengetahui pengakuan beban dalam laporan laba rugi pada PT Monfori Nusantara.

3. Untuk mengetahui penyajian pendapatan dan beban dalam laporan laba rugi pada PT Monfori Nusantara.

\section{TINJAUAN PUSTAKA}

Menurut PSAK No.23 kriteria pengakuan pendapatan biasanya diterapkan secara terpisah kepada setiap transaksi, namun dalam keadaan tertentu adalah perlu untuk menerapkan kriteria pengakuan tersebut kepada komponen-komponen yang dapat diidentifikasi secara terpisah dari suatu transaksi tunggal supaya mencerminkan substansi dan transaksi tersebut. Sebaliknya, kriteria pengakuan diterapkan pada dua atau lebih transaksi bersama-sama bila transasksi tersebut terikat sedemikian rupa sehingga pengaruh komersialnya tidak dapat dimengerti tanpa melihat rangkaian transaksi tertentu secara keseluruhan.

Pengakuan beban dalam buku Akuntansi Keuangan Stice/Stice/Skousen dibagi menjadi tiga bagian, yaitu : 1. Pengaitan atau penandingan langsung, mengaitkan atau menghubungkan beban pada pendapatan tertentu sering disebut proses matching. Misalnya, harga pokok penjualan jelas merupakan beban langsung yang dapat 'dikaitkan' atau 'ditandingkan' dengan pendapatan yang dihasilkan oleh penjualan barang dan dilaporkan pada periode yang sama dengan pengakuan pendapatan. Hal yang sama, beban pengiriman dan komisi penjualan biasanya berkaitan langsung dengan pendapatan. Beban langsung tidak hanya mencakup beban yang sudah terjadi, tetapi juga beban yang hanya diantisipasi berhubungan dengan pendapatan pada periode yang sama. Setelah penyerahan barang kepada pelanggan masih ada beban penagihan, kerugian karena tidak tertagihnya piutang usaha, dan beban garansi yang mungkin terjadi atas barang yang rusak. Beban ini terhubung langsung dengan pendapatan dan harus diestimasi serta dikaitkan dengan pendapatan yang diakui untuk periode tersebut. 2.Alokasi sistematik dan rasional, kategori pengakuan beban ini melibatkan aset yang memiliki manfaat lebih dari satu periode akuntansi. Beban aset seperti gedung, peralatan, paten dan asuransi dibayar dimuka disebar kesepanjang periode masa manfaat dengan cara yang sistematik dan rasional. 3. Pengakuan segera atau seketika, banyak beban yang tidak terkait dengan pendapatan tetapi terjadi untuk mendapatkan barang dan jasa yang secara tidak langsung membantu menghasilkan pendapatan. Karena barang dan jasa seperti ini digunakan hampir dengan segera, harga perolehannya diakui sebagai beban pada periode pembelian. 
Penelitian yang akan penulis lakukan adalah berupa study kasus, dengan mengambil data dari laporan keuangan laba/rugi. Dalam melakukan penelitian, penulis menggunakan metode Analisis Deskriptif Kuantitatif, yaitu dengan mengungkapkan kegiatan operasi yang dilakukan oleh PT. Monfori Nusantara dalam hal pengakuan pendapatan dan beban serta penyajian didalam laporan laba rugi.

Dalam hal ini penulis akan melakukan pengamatan terhadap laba atau rugi yang berkaitan dengan jumlah pendapatan yang diperoleh perusahaan. Dimana dalam pengakuan pendapatan dan beban tersebut harus berkaitan dengan penjualan terhadap perkembangan pendapatan usaha.

\section{HASIL DAN PEMBAHASAN}

Pengakuan pendapatan dan beban pada PT. Monfori Nusantara yaitu dengan menggunakan metode dasar akrual (accrual basis). Jadi, pengakuan pendapatan diakui pada saat barang diserahkan kepada pelanggan.Penggunaan metode ini menunjukan telah terjadinya piutang usaha dalam asset lancarnya. Piutang usaha tersebut timbul dari adanya transaksi penjualan barang dan jasa yang belum dilunasi oleh pelanggan. Pendapatan yang diakui oleh PT. Monfori Nusantara berasal dari sumber-sumber pendapatan yang dimiliki perusahaan sebagai komoditas utama dalam mencapai suatu tujuan perusahaan. Setiap perusahaan mempunyai sumbersumber pendapatan yang berbeda-beda tergantung dari jenis usahanya.

Dengan adanya metode akrual, perusahaan dapat mengetahui besarnya pendapatan yang diperoleh perusahaan dalam satu periode akuntansi. Ada saat pendapatan tersebut sudah diketahui maka akan mempermudah proses menentukan langkah-langkah yang akan ditempuh perusahaan dalam melaksanakan aktivitasnya. Beban diakui secara proporsional dengan pengakuan pendapataanya sehingga diperoleh "proper matching cost against revenue (metode pengakuan pendapatan sama dengan metode pengakuan beban)", beban lain diakui saat terjadinya transaksi dan sesuai dengan bukti transaksi.

Setelah perusahaan mengakui besarnya pendapatan dan beban yang telah terjadi atas penjualan tanaman, maka selanjutnya perusahaan akan menyusun laporan laba rugi sebagai dasar informasi apakah perusahaan mendapatkan keuntungan atau kerugian. Laporan laba rugi PT. Monfori Nusantara disusun oleh bagian akuntansi berdasarkan invoice, bon-bon dab bukti-bukti transaksi lainnya yang digunakan sebagai dasar bukti transaksi. Perusahaan menjumlahkan semua penjualan tanaman yang terdapat dalam invoce dan mengurangi seluruh bon-bon kas perusahaan kemudian hasilnya tersebut menunjukan adanya laba/rugi perusahaan. Sehingga dapat dikatakan bahwa perusahaan telah menunjukan saldo-saldo tersebut secara riil.

Pendapatan dan beban disajikan dalam laporan laba rugi yang merupakan bagian dari laporan keuangan. Untuk tahun buku yang berakhir pada tahun 2011 dan 2012. Perusahaan mencatat penjualan bersih sebesar Rp. 4,457,199,505,00 dan Rp. 6,757,008,968,00 dan rugi masing-masing Rp. 5,478,656,414,00 dan Rp. $1,586,723,913,00$. 
revenues

expenses

recognition,

income statement

010

and Berikut ini penulis akan menampilkan laporan laba rugi tahun 2012:

PT. Monfori Nusantara

Laporan Laba Rugi

31 Desember 2012

\section{Penjualan}

Retur Penjualan

HPP

\section{Laba Kotor}

\section{Beban Operasi}

Beban penjualan \& Marketing

Beban Perijinan

$60,592,582$

Entertaiment

3,083,609

Program Pemasaran

$104,627,400$

Biaya Angkut (penjualan)

$705,575,883$

Beban Pengemasan

$34,215,000$

Biaya Angkut (pembelian)

$24,983,863$

933,078,337

\section{Beban Umum \& ADM}

Asuransi Tenaga Kerja

$19,066,091$

Bahan Bakar

$76,088,135$

Parkir

$15,603,100$

Suku Cadang

$73,273,800$

Biaya Bank

$31,160,341$

Telephone \& Fax

$64,586,742$

Hubungan Masyarakat

$9,060,000$

Beban depresiasi kendaraan

$58,971,172$

Beban depresiasi peralatan kantor

$2,652,084$

Biaya Listrik

$12,586,100$

Entertaiment

147,600

Beban kesehatan

$73,125,333$

Biaya perjalanan dinas

$274,070,364$

Perlengkapan kantor

$136,810,180$

THR

$21,135,000$

Tukang kebun

$13,985,400$

Beban rumah tangga

$32,508,850$

Pos \& Materai

$2,988,100$

Litbang

$41,057,072$

Beban gaji

$262,719,141$

Beban pajak

$44,004,487$

ATK

$51,250,412$

Perijinan

$117,138,499$

Tenaga Profesional

$239,940,500$

Beban komputer \& software

Sampah \& Pengankutan

Beban ISO

$62,313,100$

Beban deprisasi peralatan kantor PLT

Sewa kantor 
Pendapatan (Beban) Lain-lain

Pendapatan bunga

Pendapatan lain-lain

beban bunga

beban lain-lain

Laba (rugi) kurs

Piutang Tak Tertagih

Jumlah pendaptan (beban) lain-lain

Laba (Rugi) bersih setelah pajak
$6,493,548$

$35,000,000$

$30,843,056$

0

$(80,531,889)$

0

\section{1}

Jika melihat Laporan laba rugi PT. Monfori Nusantara, perusahaan mengklasifikasikan biaya listrik dan air sebagai biaya overhead, padahal sesuai kondisi dilapangan listrik juga digunakan bersama dalam kegiatan administrasi kantor seperti pada listrik yang digunakan untuk penerangan kantor, mengoperasikan komputer dan printer. Secara akuntansi keadaan ini akan memepengaruhi harga pokok produksi menjadi lebih tinggi karena dalam pembuatan harga pokok produksi perusahaan mengakui seluruh biaya listrik, padahal semestinya dari jumlah tersebut ada sebagian yang merupakan beban kantor yang seharusnya dialokasikan pada beban administrasi dan umum.

Metode akuntansi yang diterapkan oleh perusahaan dapat mempengaruhi pendapatan total suatu perusahaan pada laporan keuangannya, begitu juga dengan beban perusahaan. Pada metode kas basis beban tidak diakui sampai uang dibayarkan walaupun beban terjadi pada bulan itu, begitu juga pendapatannya tidak diakui sampai uang diterima. Sehingga metode kas basis tidak mencerminkan besarnya uang yang sebenarnya.

Pada metode akrual basis beban dan pendapatan diakui pada saat terjadinya transaksi. Pencatatan menggunakan metode akrual mengakui beban pada saat transaksi terjadi walaupun kas belum dibayarkan, begitu juga dengan pendapatan dicatat pada saat transaksi terjadi walaupun kas atas transaksi pendapatan tersebut baru diterima.

Masing-masing basis ini memiliki kelebihan dan kekurangan, penggunaan basis kas memiliki kelebihan pada kesederhanaanya dan kemudahannya karena model pencatatannya lebih relative sedikit dibandingkan basis akrual, penggunaan basis kasnya juga memberikan informasi yang kurang akurat. Kelebihan basis akrual adalah memeberikan gambaran keuangan yang lebih akurat sehingga evaluasi kinerja terhadap biaya pelayanan dan pencapaiannya bias dilakukan. Sedangkan pada basis akrual kelemahannya adalah transalsi yang harus dicatat menjadi lebih banyak dan relative lebih rumit.

Oleh karena itu, dapat disimpulkan bahwa pencatatan menggunakan metode akrual basis lebih mencerminkan keadaan keuangan perusahaan sebenarnya. Sehingga informasi yang disediakan lebih handal dan terpercaya tentang seberapa besar suatu perusahaan mengeluarkan uang dan menerima uang dalam setiap bulannya. Walaupun metode pencatatan akrual basis lebih sulit antuk diterapkan karena akuntan harus melakukan pencatatan lebih banyak dibandingkan metode kas basis. Maka untuk mementukan metode mana yang akan diterapkan setiap perusahaan dalam hak pengakuan pendapatan dan beban, akan lebih baik jika didasari atas kepentingan perusahaan itu sendiri. 


\section{revenues and SIMPULAN}

expenses

recognition,

income statement

\section{2}

1. PT. Monfori Nusantara menerapkan metode pencatatan akrual basis dalam mengakui pendapatan atas penjualan tanaman yaitu mengakui pendapatan pada tanggal transaksi tanpa memperdulikan kapan kas diterima.

2. PT. Monfori Nusantara menerapkan metode pencatatan akrual basis dalam mengakui beban yang dikeluarkan untuk kegiatan perusahaan yaitu mengakui beban pada tanggal transaksi tanpa memperdulikan kapan kas dikeluarkan.

3. Penyajian laporan laba rugi PT. Monfori Nusantara sudah sesuai dengan PSAK No.23 karena ada kesamaan antara pengakuan pendapatan dan beban.

\section{DAFTAR PUSTAKA}

Eudia Pesparani Yirre A. L. 2010. Analisis Pendapatan dan Beban dalam Kaitannya dengan PPh terhutang. Materi pada Seminar Ilmiah STIE Kesatuan, Bogor, 2008.

Harahap, Sofyan. Syafri. 2002. Teori Akuntansi. Erlangga, Jakarta.

Ikatan Akuntan Indonesia. 2010. Pernyataan Standar Akuntansi No. 1, Edisi Revisi. Jakarta.

Ikatan Akuntan Indonesia. 2010. Pernyataan Standar Akuntansi No. 23, Edisi Revisi. Jakarta.

Ikatan Akuntan Indonesia. 2007. Standar Akuntansi Keuangan. Salemba Empat, Jakarta.

Ikatan Akuntan Indonesia. 2010. Pernyataan Standar Akuntansi Keuangan (Revisi 2010) No. 23 Pendapatan. Penerbit Erlangga, Jakarta.

Ikatan Akuntan Indonesia. 2009. Standar Akuntansi Keuangan ETAP. Penerbit Erlangga, Jakarta.

Imam Santoso. Akuntansi Keuangan Menengah (Intermediate Accounting) Buku 2. PT. Refika Aditama, Bandung.

International Accounting Standard No. 18. Revenue Statement.

Muqodim. 2006. Teori Akuntansi. PT. Ekonisia Fakultas Ekonomi UII, Yogyakarta.

Kurniawati Agustin. Analisis Penerapan PSAK Nomor 23 Dalam Kaitannya Dengan Pengakuan Pendapatan Pada Perusahaan. Materi pada Skripsi STIE Kesatuan, Bogor, 2011.

Nofryanunus. 2010. Analisis Selisih Kurs dan Pengaruhnya pada Laporan Laba Rugi PT. Cantika Hair International. Materi pada Skripsi STIE Kesatuan, Bogor, 2010.

Pengertian Pendapatan. http://www.kamusbesarbahasaindonesia.co.id

Pengertian Beban. http://www.kamusbesarbahasaindonesia.co.id

Reeve M. James, Carl S. Warren, Jonathan E. Duchac, dkk. Principles of Accounting-Indonesia Adaptation. Salemba Empat, Singapore.

Rustam. 2002. Pendapatan Menurut Standar Akuntansi Keuangan No. 23. http:www.google.co.id (digitized by USU digital library 1).

S, Munawir. 2002. Analisa Laporan Keuangan. Yogyakarta : Liberty.

Soemarso S. R. 2004. Akuntansi Suatu Pengantar 1. Edisi 5, Salemba, Jakarta.

Stice, James D, Stice, Earl K, and K. and Skousen, K. Fred, 2004. Intermediate Accounting. 15th Edition. Alih Bahasa Barlev Nicodemus. Akuntansi Keuangan, Edisi 15 buku 1. Salemba Empat, Jakarta.

Stice, James D, Stice, Earl K, and K. Fred. 2009. Intermediate Accounting. Alih Bahasa: Ali Akbar. Akuntansi Keuangan Jilid 1 Edisi 16. Salemba Empat, Jakarta. 
Supardji. 2009. Teori Akuntansi. Modul 2. Bogor; STIE Kesatuan Bogor (Diktat Kuliah)

Suwardjono. 2008. Teori Akuntansi. Edisi 3, BPFE Yogyakarta.

Thomas R. Dyckman, Roland E. Dukes and Charles J. Davis. 2088. Akuntansi Intermediate. Edisi 3 Jilid 1, Erlangga, Jakarta.

Warren Carl S, Reeve, James M. Reeve, and Fees Philip E. 2005. Accounting. $21^{\text {th }}$ Edition. Alih Bahasa: Aria Farahmita, Amanugrahani, Taufik Hendrawan. Pengantar Akuntansi. Edisi 21. Salemba Empat, Jakarta. revenues

and expenses

recognition,

income statement

013 